\title{
Brachydactyly type A4
}

INSERM

\section{Source}

INSERM. (1999). Orphanet: an online rare disease and orphan drug data base.

Brachydactyly type A4. ORPHA:93394

Brachydactyly type A4 (BDA4) is a congenital malformation characterized by brachymesophalangy affecting mainly the 2 nd and the 5 th digit. 